\title{
SUBTITLING AUDIOVISUAL HUMOUR: THE CASE OF 'EARLY ALMODÓVAR' FILMS DURING LA MOVIDA IN SPAIN (1980-1984)
}

\author{
Alejandro Bolaños García-Escribano
}

a.bolanos@ucl.ac.uk University College London

\begin{abstract}
Humour transfer on screen responds to the inner constraints of audiovisual translation. Audiovisual humour imposes further challenges to translators because of its polysemiotic nature. This can be undeniably observed in auteur films that are specifically contextualised in a historical and sociocultural context, such as the 'early Almodóvar' films. Pedro Almodóvar's first four films (1980-1984) were created during the Spanish Movida movement after dictator Franco's death, corresponding historically to the political Transition of Spain towards democracy. These films have been so important that they can now be considered samples of audiovisual expression of Spanish Movida changes. Verbally Expressed Humour elements in these films represent compelling examples of translation challenges that respond to both the complexity of wordplay transfer and the cultural components of Spain in the 1980s. Sets of examples from Almodóvar's first films illustrate the difficulties of transferring Verbally Expressed Humour elements in subtitling. This paper finds that humour transfer is accomplished in many different ways by subtitlers, whose translation techniques can be analysed following descriptive studies specifically focused on Audiovisual Translation.
\end{abstract}

\section{Resumen}

La transferencia del humor para la pantalla responde a las restricciones propias de la traducción audiovisual. El humor audiovisual impone mayores retos a los traductores por su naturaleza polisemiótica. No cabe ninguna duda de que esto es palpable en aquellas películas de autor que se sitúan en un contexto histórico y sociocultural específico, tales como las películas del primer Almodóvar. Las cuatro primeras películas de Pedro Almodóvar (1980-1984) surgen durante la Movida española tras la muerte 
del dictador Franco, tiempo histórico correspondiente a la Transición democrática española. Estos filmes han sido tan importantes que hoy se consideran muestras de expresión audiovisual de los cambios que ocurrieron en la Movida. Los elementos de humor expresado verbalmente que aparecen en las películas representan retos de traducción de gran complejidad, tanto por la transferencia del juego de palabras como por el componente cultural de la España de los ochenta. Una serie de ejemplos extraídos de los primeros filmes de Almodóvar ilustra las dificultades que entraña la transferencia de elementos de humor expresado verbalmente en la subtitulación. Este estudio señala que los subtituladores consiguen transferir el humor de muchas formas distintas. Las técnicas de traducción de los anteriores pueden analizarse siguiendo estudios descriptivos centrados específicamente en la Traducción Audiovisual.

Keywords: Humour. Subtitling. Translation. Verbally expressed humour. Almodóvar. Movida.

Palabras clave: Humor. Subtitulación. Traducción. Humor expresado verbalmente. Almodóvar. Movida.

Manuscript received on April 19, 2016 and accepted for publication on October 10, 2016.

Para enlazar con este artículo / To link to this article:

http://dx.doi.org/10.6035/MonTI.2017.9.8

Para citar este artículo / To cite this article:

BOLAÑOS GARCíA-ESCRIBANO, Alejandro. (2017) "Subtitling audiovisual humour: The case of 'early Almodóvar' films during la movida in Spain (1980-1984)." In: Martínez Sierra, Juan José \& Patrick Zabalbeascoa Terran (eds.) 2017. The Translation of Humour / La traducción del humor. MonTI 9, pp. 219-247. 


\section{Introduction}

Verbally Expressed Humour (VEH) represents a linguistic and culture-dependent translation challenge in subtitling. VEH is thus observed as a fully valid theoretical subject within the framework of Translation Studies (TS) - and more specifically in Audiovisual Translation (AVT) - as well as in Humour Studies. The present case study is rooted in at least three main disciplines and will hence cover several theoretical backgrounds with the sole aim of evaluating the functionality of VEH elements in subtitling.

This study runs parallel to an unpublished case study on socio-historical implications of Spanish film director Pedro Almodóvar's early films (1980s) in contemporary historical and cultural studies in connection with Movida movement in Spain (Bolaños 2014). The present paper advocates the use of film studies and cultural studies research for TS-related case studies of audiovisual texts; in this case, a set of examples of VEH content extracted from the first four films by Almodóvar will be analysed. These early films, produced between 1980 and 1984, are marked by an era of social, political and cultural transformation in post-dictatorship Spain. They are also the symbolic representations of the so-called 'early Almodóvar' aesthetic (Gubern 2014) that is chronologically simultaneous to the Movida movement in Spain.

As will be outlined throughout this paper, Almodóvar's films created during La Movida were not only a process of renegotiating Spanish cultural boundaries after dictator Franco's death in 1975, but they also resort to VEH elements that are highly interesting from the point of view of humour transfer in subtitling. This study aims to shed light on the application of VEH-related translation techniques throughout context-specific films of historical relevance. 'Early Almodóvar' subtitled film versions distributed in the United Kingdom since 2005 have been used for this descriptive study.

\section{Towards a definition of Verbally Expressed Humour}

Humour - understood as any communication that generates a positive cognitive or affective response from listeners (Sen 2012: 1) - is an inner characteristic of certain textual genres. Although it can, very arguably, result from mere 
linguistic transfer (Schwarz 2010: 71), humour has a precise communicative function too (Attardo 1994: 213). In fact, Zabalbeascoa (2001: 256) differentiates jokes depending on their importance in discourse: high importance, medium importance, low importance and negative importance. The communicative component of jokes justifies their inclusion as part of the discourse, and, in the case of AVT, of the audiovisual text as well, the latter being understood as "a semiotic construct comprising several signifying codes that operate simultaneously in the production of meaning" (Chaume 2004: 16). Jokes can be present in any audiovisual programme, irrespective of genre, despite some generally containing more humour-related content than others, such as sitcoms, comedy TV series and comedy films, to name but a few.

VEH is grounded on several theories of humour, but especially on the General Theory of Verbal Humour (GTVH), which was first introduced by Attardo \& Raskin (1991) as a result of combining Raskin's script-based semantic theory of humour and Attardo's five-level model (Attardo \& Raskin 1991: 329). Other humour theories include the relief theory, the superiority theory and the incongruity theory (Meyer 2000: 312-314). Attardo \& Raskin (1991: 331) have, however, declared their wish for GTVH to be totally uncoupled from other theories, especially incongruity-related theories, as:

$[\mathrm{H}]$ umour is created out of a conflict between what is expected and what actually occurs in the joke. This accounts for the most obvious feature of much humour: an ambiguity, or double meaning which deliberately misleads the audience, followed by a punch line (Ross 1998: 7).

For this study, despite the vastness of the literature, VEH will be defined as follows: "a projection, on a word level, of the humour quality in a set of actions or situations" (Fuentes 2000: 14), which can either be wordplay or content references play. Hence, a direct association is established between VEH elements and wordplay, following Lipka (2009), and other theoretical frameworks proposed by Blake (2007), Crystal (1998), Chiaro (1992), Nash (1985) and Redfern (1984). In the words of Delabastita, wordplay is:

$[T]$ he general name indicating the various textual phenomena (i.e. on the level of performance or parole) in which certain features inherent in the structure of the language used (level of competence or langue) are exploited in such a way as to establish a communicatively significant, (near)-simultaneous confrontation of at least two linguistic structures with more or less dissimilar meanings (signifieds) and more or less similar forms (signifiers) (1993: 57).

Delabastita (1996), Gottlieb (1997) and Vandaele (2011) offer narrow classifications of VEH elements that also correspond to Zabalbeascoa's (1996) elaboration on language-dependent jokes in audiovisual texts. The resulting 
VEH types can be summarised as pertaining to two levels that are interconnected: denotation and connotation. On the one hand, denotation includes word-specific problems (i.e. wordplay), such as homophony, (lexical, collocational, phrasal) homonymy, homography and paronymy. On the other, connotation includes semantic problems (tropes) and sociolinguistic-related problems (i.e. lectal value), which originate in aspects such as linguistic variation and culture-bound references. This study focuses on wordplay at a micro-textual level, but special attention is paid to the importance of tropes.

\section{The translatability of Verbally Expressed Humour in Audiovisual Translation}

Much research has been carried out on humour-related issues in TS in the past, covering prescriptive, descriptive and empirical aspects of the translation of humour shifts. It has traditionally been considered that "the relative or absolute untranslatability is generally related to cultural and linguistic aspects" (Vandaele 2010: 149) in translation. Yet this assumption does not tally with AVT - the polysemiotic nature of the audiovisual text poses constraints that need to be solved at a linguistic level with the aid of technology (e.g. subtitling software solutions in the case of subtitling and captioning), and the visual support thus introduces a coherence subordination effect that restricts humour transfer on screen.

According to previous wordplay classification proposals, such as Zabalbeascoa's (1996), the inner particularities of audiovisual humour should by no means be disregarded in case studies such as the one presented in this paper. In fact, what we can say of the translation of audiovisual texts containing humour shifts is the following:

[...] they can be hampered by technical, linguistic and cultural constraints. As a result, when it comes to its translation an interdisciplinary approach is needed in order to understand how humorous stimuli/effects on the target audience. In this sense, the target viewer of a subtitled humorous film must relate to both the original dialogue and the original action so that communicative cooperation between the source and the target versions can be achieved (Veiga 2009: 160).

Regarding the ins and outs of translating wordplay, Low (2011: 59) states that "for those who see translating as an essentially verbal process using limited tools like synonyms and transpositions, translating a joke means creating an amusing target text (TT) that is nearly identical to the source text (ST)". This has led in the past to the common assumption by a number of academics that VEH mandatorily leads to the question of untranslatability. 
Following this argument, Attardo (2002: 192) states that wordplay cannot be considered "absolutely" translatable, if it is considered that the connotative level of meaning differs from one language to another. This clear position points to cultural difference as the cornerstone reasoning for the argument that translation is never "absolute", which seems convenient when highlighting the functional importance of context. In Schröter's (2010: 142) understanding of wordplay transfer, language play is translatable provided that a broader definition of translation is adopted. This position reflects nothing but an attack against purely linguistic viewpoints on humour translation and linguistic approaches in TS in general. That is, it cannot be assumed that translation has to do with words only - on the contrary, it involves a number of factors that go far beyond the text (culture, language, profession and society, among others) and that have been the object of study by TS academics for the last three decades.

Cultural differences are an essential consideration of translation as a professional activity, and this factor provides clear examples of the interaction between cultures (Martínez-Sierra 2004: 149). It can thus be argued that dealing with humour in translation also calls for a cultural approach, professionally, but also theoretically. Since both verbal and non-verbal communication are undoubtedly held in a specific socio-cultural context, it can also be assumed that humour is deeply grounded in culture - hence the justification of a cultural approach to translation if translation is seen as a process of intercultural communication (House 2016: 13). Nonetheless, a more recent approach to translation, following the cultural turn in TS, is more concerned with social difference, highlighting that translations are the product of people (translators), leading to the existence of a sociology of translation (Buzelin 2013: 186) that goes hand in hand with translation activism and the translator's invisibility. Unfortunately, the sociology of translation does not seem to offer a very solid framework in Humour Studies in the context of the present study. In addition, the scope of this study does not permit the development of focused discussion on the social aspects of humour in AVT.

Apart from that, humour units can also be considered at a supra-segmental level, and the whole audiovisual text represents a translation unit itself. This textual approach, illustrated in Chiaro (2006), Martínez-Sierra (2008) and Varga (2011), among others, may correspond in general terms with the functionalist approach:

[W] hen dealing with humour, translation professionals do not necessarily need to execute a word-for-word, or even sense-for-sense, exercise of faithfulness. Instead, they need to be especially faithful to what is behind allusion 
references and humoristic commentaries. This leads to an adaptation, rather than a respect or maintenance, of these elements that, as for the source language and culture, are unknown beforehand by the potential receiver in order to assure the identification of these elements. This identification guarantees, firstly their recognition, and secondly the source text's reaction to its humoristic intentions (Fuentes 2000: 37-38; my translation).

A firm opposition to considering untranslatability an inherent criterion of wordplay is maintained throughout this research. Going beyond prescriptive (if not archaic) precepts of translation from classical linguistic theories, faithfulness falls under its own weight when considering translation as a purposeful professional activity, in which word-for-word rendering would just be impractical. This statement has already been thoroughly discussed in academia in the past, following Skopos theory-related ${ }^{1}$ research which, for logistical reasons, will not be reproduced in this study.

\section{VEH: a major translation challenge in subtitling}

Subtitling is considered a sub-mode of AVT that has long been known as "constrained translation" (Mayoral, Kelly \& Gallardo 1988: 102), for there are multiple codes implied in the (visual and aural) conveyance of meaning. Subtitles being "snippets of written text superimposed on visual footage that convey a target language version of the source speech" (Pérez González 2014: 16), there are a number of constraints that subtitlers must take into account, such as reading speed, limitations on the number of characters per line, line division and shot and scene changes, to name but a few. As illustrated by Díaz-Cintas (2003: 149-153), the main strategy in subtitling boils down to condensation, be it partial (reduction) or total (omission).

Subtitling is considered "vulnerable translation" (Díaz-Cintas 2003: 43). In audiovisual programmes, subtitles are cued on screen at the same time as the original audio band; that is, the target audience are able to evaluate and critique the translation from their own knowledge of the source language and culture, and, this being the case, "subtitling establishes a competition between text and image" (Cornu 2014: 223; my translation). The exposure to the original script in the audio poses challenging situations when VEH is at stake - for instance, any canned laughter in the soundtrack or other kind of laughter on screen calls for immediate action in the subtitles. This has to do with isochrony because if subtitles fail to convey the VEH element at the right time, "the viewers will be under the impression that they are missing

1. To know more, please refer to Christiane Nord (1997), among others. 
something" (Díaz-Cintas \& Remael 2007: 216). Audiovisual humour is thus undeniably conditioned by its perception (Veatch 1998: 163), mainly because subtitles represent a sort of distraction for the audience, and the spotter must thus minutely work out its exposure timing.

Along with general subtitling conventions (Díaz-Cintas 2003), humour passages call for an overall strategy and specific translation techniques to render VEH elements in the subtitles. The overall strategy adopted by the subtitler usually depends on the overall translator's subtitling competence and experience. The translation techniques, also known as procedures and not to be confused with strategies, as outlined by Hurtado \& Molina (2002), would thus be the discursive, contextual, functional procedures that aim at analysing and classifying how translation equivalence works in a pair of source and target texts, at the micro-unit level. Translation techniques ${ }^{2}$ are the materialisation of the translator's strategies in the translation process and its outcome.

Below are three major academic contributions on VEH translation techniques specifically applied to AVT.

\begin{tabular}{|c|c|c|}
\hline Chiaro (2010: 6-7) & Fuentes (2010: 186) & Gottlieb (1997b: 210) \\
\hline $\begin{array}{l}\text { 1) Leaving the VEH } \\
\text { unchanged; } \\
\text { 2) Replacing the source } \\
\text { VEH with a different } \\
\text { instance of VEH in the } \\
\text { TL; } \\
\text { 3) Replacing the source } \\
\text { VEH with an idiomatic } \\
\text { expression in the TL; } \\
\text { 4) Ignoring the VEH } \\
\text { altogether. }\end{array}$ & $\begin{array}{l}\text { 1) Literal translation; } \\
\text { 2) Explanatory translation; } \\
\text { 3) Compensatory } \\
\text { translation; } \\
\text { 4) Effective or functional } \\
\text { translation. }\end{array}$ & $\begin{array}{l}\text { 1) Verbatim rendering, } \\
\text { with or without } \\
\text { humorous effect; } \\
\text { 2) Adaptation to the local } \\
\text { setting to maintain } \\
\text { humorous effect; } \\
\text { 3) Replacement by } \\
\text { non-wordplay; } \\
\text { 4) Not rendering, using the } \\
\text { space for neighbouring } \\
\text { dialog; } \\
\text { 5) Insertion in places } \\
\text { where the TL renders it } \\
\text { possible. }\end{array}$ \\
\hline Dubbing & Dubbing / Subtitling & Subtitling \\
\hline
\end{tabular}

Table 1 - Translation techniques for VEH elements in AVT-specific research.

None of them seem to have observed the exhaustive classification offered by Hurtado \& Molina (2002), which is indeed most useful for product-oriented

2. Translation technique as a concept is used in translator training but has been somewhat abandoned in academic research of professional translating practices. 
analyses of subtitles in case studies. Adopting the techniques that could apply to subtitling results in the following list of VEH translation techniques:

- non-translation: calque, borrowing or reduction;

- explanation: amplification, description;

- non-wordplay replacement: compression, generalisation, modulation, particularisation, transposition; and

- wordplay replacement: idiomatic compensation, discursive creation, substitution, variation.

VEH content poses a highly complicated challenge for subtitlers, due to technical, linguistic, textual, cultural and functional restrictions that operate at the same time in the polysemiotics of audiovisual texts. Rendering "certain voice tones, irony, humour state, euphoria or other rhetorical resources" (Castro 2001: 282) in a subtitled version can be anything but simple, which is why some jokes in the original version (OV) are completely replaced by new ones, compensated in other passages or completely erased from the subtitles. And yet, it has also been suggested that careful attention to VEH units may result in higher quality standards in the TL (Schröter 2010), although this is an assumption that has not been empirically proved to this day, and which calls for further investigation. As Perego (2014: 10) argues, the evaluation of quality based on wordplay transfer in subtitling seems to have caught the attention of many researchers in the past, even though there now seems to be a shift towards less common AVT modes, such as subtitling for the deaf and the hardof-hearing and audio description, as seen in De Rosa et al. (2014).

\section{Materials: the 'early Almodóvar' films (1980-1984)}

For this case study, the audiovisual corpus includes the first four full-length films by Pedro Almodóvar (1980-1984), which are distributed in the UK today in DVD format, namely:

- 1980: Pepi, Luci, Bom and Other Girls on the Heap (PLB from now on), distributed by Optimum Releasing (2005). A policeman rapes a young, independent woman named Pepi at her flat in Madrid. Desperately aiming at selling her virginity for easy money, Pepi now seeks revenge, and persuades Bom and her music group to beat up the policeman. But they mistakenly end up attacking his twin brother, and leave the policeman unharmed. Pepi decides to take action herself, and meets the policeman's wife, Luci, a prudish housewife who feels a strong attraction to suffering pain. One day, while teaching embroidery to Pepi in 
her flat, Bom arrives and pisses on her face, pleasing Luci and assuming the role of a dominant lover. From then on, Pepi, Luci and Bom cultivate their friendship on the basis of a libertine lifestyle in Movida Madrid. They enjoy the nightlife with the youth until one day Luci is beaten by her husband. Her need of pain being satisfied once again by her husband, Luci ends her friendship with Pepi and Bom for good.

- 1982: Labyrinth of Passion (LP from now on), distributed by Tartan Video (2007), and the old VHS version (1990). Riza Niro, the son of Tiran's deposed emperor, arrives in Madrid. In one of his first sexual encounters with other men, he sleeps with Sadec, one of the Islamic terrorists who came to Madrid to kidnap him. Riza also meets Fabio, a gay punk who introduces him to the libertine lifestyle Movida Madrid has to offer. At a concert by the Ellos music group, their singer falls down the stairs, and Riza ends up being their new lead vocalist. At the same time, nymphomaniac Sexilia, the daughter of a well-known doctor, meets Queti, a dry cleaner who is being harassed by her medicated father. Riza Niro is not only chased by the group of Tiran terrorists, but also by princess Toraya, the former wife of Tiran's deposed emperor. Sexilia and Riza then meet and start a love affair. Thanks to her psychoanalyst, Sexilia remembers that they had already met during a holiday vacation in Costa del Sol when they were preteens. She also finds out that her nymphomaniac desires originate in her seeing Toraya abusing Riza at that time. Riza and Sexilia eventually take flight from Barajas to the capital of Tiran in the Caribbean, Contadora, while the terrorists kidnap Toraya instead.

- 1983: Dark Habits (DH from now on), distributed by Optimum Releasing. The Order of the Humiliated Redeemers offer shelter and redemption to fallen women in their convent. Yolanda, a cabaret singer who causes her boyfriend to overdose on drugs, hides in the convent where Mother Superior, a lesbian drug addict, is one of her fans. Yolanda is assigned the room in which Virginia, the daughter of a rich marquise, used to be imprisoned. Another four nuns comprise the convent - Sister Manure cooks under LSD hallucinations, Sister Damned cares for a Bengal tiger breeding in the cloister, Sister Snake creates original cloth designs for religious sculptures, and Sister Sewer Rat writes lurid novels about the women staying in the convent under the pen name Concha Torres. One day, Mother Superior receives a letter from Virginia who had a son before her death. After failing to blackmail the marquise with the letter, Mother Superior gets involved in the 
illegal drug trade to fund the convent, which had received a threat of closure. Yolanda sings in honour of the Mother Superior for her birthday party, then intercepts the letter and gives it to the marquise. The upcoming Mother General announces the dissolution of the convent, and Mother Superior laments Yolanda's departure.

- 1984: What Have I Done to Deserve This? (WH from now on), distributed by Optimum Releasing. Gloria, housewife and occasional cleaner, lives with her husband, her mother-in-law and her two children in a small apartment located in a working-class neighbourhood on the outskirts of Madrid. Her oldest son, Toni, is a drug-dealer, whereas her younger son, Miguel, is a declared homosexual. Her husband, Antonio, still longs for a German woman, his former employer, and cares for neither his family nor Gloria. Antonio's mother is an unhappy old woman who desperately wants to move back to her hometown in the countryside. Gloria is addicted to over-the-counter drugs, and hysterically assaults her husband and kills him in the kitchen. When the investigators, one of whom is an impotent policeman who has had an affair with Gloria at the gym, come to the apartment, the only witness to the crime is her mother-in-law's lizard called Money. Gloria receives the support of Juani, an Andalusian woman whose only daughter has a strange mental power, and Cristal, a prostitute who lives opposite their flat.

As outlined in Bolaños (2014), Almodóvar's four early films share the following characteristics:

- they are subject to the same historical and socio-cultural contextualisation: Spain in the early 1980s;

- they were created by a then-emerging film director who is now internationally renowned in film studies;

- they are idiosyncratic to Spanish contemporary history and culture;

- they present stereotypical Spanish characters that can be analysed in regard to their social and linguistic backgrounds; and

- they result from a creative, artistic production that, despite the lack of monetary resources, achieves a masterfully crafted script which draws the attention of academics of contemporary history, cultural studies and film studies today.

Several TS scholars, such as Garzelli (2014), Lomeña (2009), Rox (2008), Roussou (2005) and Díaz-Cintas (2001), have already covered the translation of Almodóvar's films in the past. Apart from language-related discussions, the 
social and cultural implications of Almodóvar's first four films can be considered from a historical perspective.

Almodóvar has been labelled a "postmodern" film director because of the original characteristics of his works: the influence of classic films and melodrama, the dominant presence of female characters, music, the presence of feelings and passion, the female point of view regarding men, the significance of representation, the accusation of anti-historicism, and camp (Rox-Barasoain 2008: 126).

Not only did Pedro Almodóvar modernise Spanish cinema in the late $20^{\text {th }}$ century, but he also became a symbol of a social, cultural, artistic, political movement commonly known as Movida (Berthier 2009). This movement was an authentic symbol of the cultural changes that occurred in Spain during the Transition (Fouce 2000) and originated in an ever-changing social landscape as described by Martínez-Vasseur:

Spain in the 80s is still today a metamorphic, mutational, hotbed of all types of Movidas that seem to be created by charm after the dictator's death. This new Spain originated, however, in the economic, social, cultural transformations that took place back in the 1960s and that consolidated, like a giant kaleidoscope, by the end of Franco's regime and during the Spanish transition to democracy (2010: 171; my translation).

Murcia (2007) states that Almodóvar's cinema analyses Hispanic culture through a lavish use of stereotypes and clichés. In fact, auteur films, such as Almodóvar's, hide a number of translation challenges that go beyond the mere semantics of spoken dialogue.

[I]n some cinematographic productions, which are known as "author films" or "independent films", directors decide to use a language marked by a certain degree of orality with aesthetic, realistic, expressive or ideological purposes. In several of these films, the director is also the scriptwriter and, sometimes, the main character. Therefore, even if dialogues are based on a written script, they are constantly evolving during filming (Romero 2011: 19).

These four films can therefore be considered audiovisual examples of how the social and cultural transformations occurring in this ever-changing Spain are reflected through the theme, the historical context and the diegesis of these film productions. This fact adds importance to the potential value of connotation present in VEH elements.

\section{Analysis of Verbally Expressed Humour in the films}

In the following paragraphs, a set of examples of VEH elements contained in the script of these four films will be discussed. By no means does this study aim at presenting quantitative data; on the contrary, its goal is the achievement of 
a descriptive discussion of humour transfer in subtitling. The analysis is thus comprised of 14 examples only. The analysis will cover the cultural component and the humorous function of the VEH elements, as well as how they have been functionally rendered into the subtitled versions in English distributed in the UK today. Besides, LP will also encompass the subtitled VHS version available online via UCL's Self-Access Centre Database. The passages will be presented as follows.

\begin{tabular}{|c|c|c|}
\hline & Example no. XX & \\
\hline ST [Source Text] & BT [Back Translation] & S [Subtitles] \\
\hline XX & XX & XX \\
\hline
\end{tabular}

As discussed in section 2, following mainstream research in VEH, the main types of linguistic wordplay analysed in the films are the following: homophony, (lexical, collocational, phrasal) homonymy, homography and paronymy. Almodóvar's dialogues include many VEH elements that are indeed related to other linguistic and sociolinguistic issues, such as culture-bound references, linguistic variety and register. With the aim of including connotation-related VEH elements, the following category has been added: tropes (figurative language).

The examples have been analysed in terms of verbal rendering in the English subtitles following the translation techniques in section 3.

\subsection{Homonymy}

Vandaele's (2011) distinction between homonymy, homography and homophony has little practical use in Spanish. Due to its inner nature, homographs in Spanish will always be homophones in spoken discourse as well. Not only that, but in the case of audiovisual programmes, homographs are very rarely found, mainly because they would be shown as inserts or text on screen. For instance, inserts including homographs are often read aloud in the dialogue or sound track, and are thus homophones at the same time (e.g. example 3). Hence, homonymy will hereby encompass homophones and homographs; that is, words that differ in meaning, but that are written or pronounced identically.

In PLB, after a quarrel with her father on the phone, Pepi sets off to work as a creative writer for an advertising agency. Her first project is a TV commercial featuring Cecilia Roth about a new model of panties that absorb urine, transform farts into perfume and can be manually turned into a sex toy. The name of these panties is 'PONTE' which stands for the imperative second-person forms of the verb 'to put on' and 'to get turned on'. This element seems to 
have been correctly spotted and transposed into English with the imperative second-person form 'PUTON', although the sexual connotation is obliterated. Besides, the final rhyme and the catchphrase of the commercial have been conserved (idiomatic compensation).

Example no. 1 (PLB)

ST

NARRACIÓN DEL ANUNCIO: Las bragas

PONTE contienen una sustancia que transforma el olor de sus pedos en el perfume más delicado. [...] Las bragas PONTE están compuestas de unas partículas que absorben totalmente el líquido de su orina, cambiando el color de las mismas. Es como si estrenara unas nuevas bragas. [...] Las bragas PONTE, cuidadosamente enrolladas, adquieren una consistencia que, a falta de algo mejor, pueden hacer las funciones de un apasionado compañero. INSERTO: Hagas lo que hagas, PONTE bragas.
BT

AD NARRATION: PONTE panties contain a substance that transforms your farts' smell into the most delicate perfume. [...] PONTE panties are made of particles that fully absorb your urine liquid, changing the colour of the panties. It will be like using a new pair for the first time. [...] PONTE panties, carefully rolled, acquire a consistency that, in the absence of anything better, may fulfil a passionate partner's functions.

TEXT ON SCREEN: Whatever you do, PONTE panties.
S

PUTON panties contain a substance

which transforms the smell of your fart into an elegant perfume.

PUTON panties are made from fibres which completely absorb your urine

and change their colour, as though you'd put on a new pair.

PUTON panties, carefully rolled, acquire a consistency which, in the absence of anything better

can fulfil the role of a passionate companion.

PUTON panties

FOR ALL EVENTUALITIES

In PLB, transvestite Fabio McNamara mutters some sentences in English to introduce the Bomitoni Group, which plays a rather extravagant concert in front of an excited audience. In doing so, he pronounces the first letter as a $/ \mathrm{v} /$ and retches when saying the name of the group which confirms the double connotation of this wordplay. Bomitoni may well be a composite noun of two components, Bom and Toni, but also a homophone for vomitona ('big vomit' or 'bad turn'). If this was not clear enough in Spanish, one of Toni's friends pukes on the floor just before they start playing because he is 'on a real downer' (тиеrmo). In this case, the wordplay has been calqued in the subtitles, thus losing its double sense and creating conflict with the visuals. 
Example no. 2 (PLB)

ST

PÚBLICO: Bomitoni!

Bomitoni! Bomitoni!
BT

CROWD: Bomitoni!

Bomitoni! Bomitoni!
$S$

Bomitoni!

In the first scene of $L P$, Fabio McNamara extends a brief note to Riza Niro where an instance of wordplay is introduced with the reference to 'Pheliz'. This word sounds like feliz ('happy') and its ending is also the first name of the wellknown actress Liz Taylor (added between circle brackets in the note). Also, the poor grammar and number of spelling mistakes in Spanish indicate a rather low educational background from its author, Fabio. The subtitles emulate the wordplay by changing the celebrity to Cher. An association can be established with its double meaning ('to cher') and conserve the pun (discursive creation). This pun was not reproduced in the old VHS version (reduction). This decision is unjustified, and represents a functional infelicity because the ST can be read on screen. The VHS version of the film denigrated this pun with the following subtitle: "I would really like to make / you happy this afternoon."

Example no. $3(L P)$

ST

INSERTO NARRADO: Si, me guxtaria hacerte pheliz (taylor) exta tarde
BT

NARRATED TEXT ON SCREEN: Yes, I would like to make you Pheliz (Taylor) this afternoon
$S$

"Yes, I'd like to Cher something with you this evening."

At one point in the same film, in one of Almodóvar's "recurrent appearances in drag" (Ballesteros 2009: 90), he plays on a pun with the personal pronoun ellos (third person plural) and a music band called 'Ellos'. This metalinguistic joke is completely lost in the subtitled version (calque), although it was fully conserved in the old VHS version. Instead of keeping 'Ellos', the subtitler of the VHS version substituted the Spanish proper noun for one of its corresponding forms in English grammar ('Them'). This decision aims at preserving intertextuality and humorous references throughout the film. In addition, the VHS version transliterates the name of the group with the following subtitle: "Listen, "The Melancholics" / can't play." 
Example no. 4 (LP)

ST

\section{HOMBRE}

DESCONOCIDO: Oye, que Los Melancólicos no pueden actuar.

Vosotros sabéis por

qué, claro.

PEDRo Almodóvar:

Ya, ya.

HOMBRE

DESCONOCIDO:

Entonces van a salir

Ellos en su puesto.

PEDRo Almodóvar:

¿Ellos? Ellos. Salen

Ellos.

HOMBRE

DESCONOCIDO: A ver

si...

FABIO MCNAMARA:

¿Qué?

PEdRo Almodóvar:

¡Ellos!

[...]

Pedro Almodóvar: Su

nombre es Ellos, pero

mientras ellos vienen,

aquí mi amiga y yo

vamos a improvisar

una bonita canción...
BT

UNKNOWN MAN: Hey, Los Melancólicos cannot perform. You know why, of course. PEDRo Almodóvar:

Yeah, yeah.

UNKNOWN MAN: So

Ellos will come up on stage instead of them. PEDRo Almodóvar:

Ellos? Ellos. Ellos

come up on stage.

UNKNOWN MAN: Let's

see if...

FABIO MCNAMARA:

What?

Pedro Almodóvar:

Ellos!

[...]

Pedro Almodóvar:

Their name is Ellos,

but while they come, my girl friend and

I will improvise a

beautiful song.
S

Los Melancólicos can’t perform

-You know why, of course.

-I know.

-So Ellos will perform instead. -Ellos.

Ellos will perform. Ellos. [...]

Their name is Ellos. But until they arrive, my friend and I will improvise a song

Almodóvar's cameo as a fanzine writer and photo novel creator is also introduced in LP. In the middle of a porn photograph session starring Fabio McNamara, Almodóvar plays with language to mix literary and sexual language. He jokes with the expression correrse which can either mean 'to move over' or 'to ejaculate'. As seen in the example below, the VHS version obliterated the sexual connotation (generalisation) - "Great. Now, move over a bit". But the DVD version does the opposite (idiomatic compensation) and renders the wordplay functionally. 
Example no. $5(L P)$

ST

PEDRO ALMODÓVAR: ¿Sí? Muy bien. Bueno, córrete un poquito.
BT

Pedro Almodóvar: Yes? Very good. Well, come a little bit.
$S$

-Yes? Very good. Now, come a little.

Juani teaches her daughter Vanesa how to use the washing machine in $\mathrm{WH}$, but she is a spoiled child and does not like to help her with housework. Vanesa asks for permission to watch the TV instead of programming the washing machine, but Juani jokes about it and tells her to put the 'programme' on the washing machine instead. In this case, the joke has been calqued, transposing the noun into a verb, but it does work as a functional rendering as well.

Example no. $6(\mathrm{WH})$

ST

JUANI: Venga, echa el jabón. Venga, ique es para hoy!

VANESA: Quiero ver el programa de la tele.

JUANI: ¿El programa?

Eso, pon el programa.
BT

JUANI: Come on, put the soap in. Come on, hurry up!

VANESA: I want to watch the TV programme. JUANI: The programme? Yes, choose the program.
$S$

Now, put the soap in.

Come on, hurry up!

I want to see the TV programme.

That's right,

go ahead and program it.

Cecilia Roth's fleeting intervention in $\mathrm{WH}$ as a commercial actress represents an excellent example of homophony. She represents a woman whose face accidentally gets burnt by her partner when the latter brings her a cup of coffee in bed. She then says she was molida ('knackered'), which in Spanish establishes a semiotic link with the visuals: it refers not only to the state of being extremely tired, but also to something that has been ground, such as coffee. This reference to coffee has been neutralised (generalisation), although the translator could have modulated it by using some idiomatic expression, such as 'dead beat', 'whacked out' or even 'knackered'. 
Example no. 7 (WH)

ST

CHICA DEL ANUNCIO: Y, a la mañana siguiente, yo estaba molida y no veía el momento de levantarme. Pero él se levantó, movido, supongo, por el amor que sentía por mí, para prepararme una taza de café. "El café”. ¡Cariño! Nunca olvidaré... esa taza de café.
BT

AD GIRL: And, the next morning, I was knackered, so I couldn't find the momentum to get up. But he got up, moved, I suppose, by the love he felt for me, to make me a cup of coffee. "The coffee". Darling! I shall never forget... that cup of coffee.
S

The next morning, I was so tired I simply could not get up. But he got up, moved by his love for me, I guess,

to make me a cup of coffee. "Coffee". Darling! Never will I forget that cup of coffee.

\subsection{Paronymy}

The difference between homonyms and paronyms is based on the degree of orthotypographical similarity between a pair of words. Paronymy occurs when words are pronounced or written very similarly, but not identically. This linguistic phenomenon is thus a very common resource for wordplay, allowing the creation of jokes based on phonetic deformations, sound analogy and other paronymy-specific resources.

In PLB, Almodóvar's cameo in a sequence called Erecciones Generales ('General Erections'), a social game where a group of young men compete against each other to see who has the biggest penis. Emulating a TV show, Almodóvar is the host of the game and the one measuring the male members, whereas Pepi plays the role of assistant. The joke lies in the deliberate confusion between elecciones and erecciones. This phonological minimal pair also works in English both in its spelling and in its pronunciation, so it has been calqued and functionally rendered in the subtitles. 
Example no. 8 (PLB)

ST

PEDRO Almodóvar: Y ahora, nuestro concurso: "Erecciones Generales". La gran sorpresa de la noche. "Erecciones" consiste en que el que tenga la polla más grande, más esbelta y más descomunal, y más perfecta, será nombrado rey del resto de la noche.
BT

PEDRo Almodóvar: And now, our competition: "General Erections". Tonight's big surprise. "Erections" consists of... whoever's got the biggest cock, the most slender, enormous, perfect cock, will be named king for the rest of the night.
S

And now, our competition:

"General Erections".

Tonight's big surprise,

In "Erections", the guy

with the biggest cock,

the most slender,

enormous, perfect cock,

will be named King for the night,

In LP, Riza Niro tells Fabio McNamara that he must disguise himself for his upcoming concert, but his hair is not long enough for an extravagant hairstyle. The latter, whose dialogues are usually quite witty and irreverent throughout the film, responds by playing with sound similarity between 'queen' and 'Halloween' as follows. This wordplay has been completely neutralised in the subtitles of the DVD version (generalisation), whereas an attempt was made to transfer it in the VHS version, merely by adding an apostrophe at the end of the word as follows: "I'll make you the Queen of / Hallowe'en."

Example no. 9 (LP)

ST

FABIO MCNAMARA:

Haré de ti la reina de Hallo-Queen.
BT

FABIO MCNAMARA: I will make of you the queen of "Hallo-Queen".
S

I'll turn you into the queen of Halloween.

In $W H$, Gloria is addicted to sniffing glue, as well as to some over-the-counter medicines such as minilip, the proper noun used for the legal amphetamine in Spain until the 1980s. This minilip makes you feel awake, as her son Miguel remarks, and is translated as 'No-Doze' (substitution), which sounds like 'no dose', also similar to Novartis's caffeine caplets called NoDoz. Later on, Gloria goes to a nearby pharmacy to buy some tablets, but they are no longer on sale 
due to recent legislation, so she asks for other similar drugs that were also forbidden by that time.

Example no. $10(\mathrm{WH})$

ST

GLORIA: ¿Quieres un minilip? Por lo menos te quitará el hambre. MiguEL: No, me pone nervioso. Mira cómo estás tú.

GLORIA: ¿Cómo estoy yo?
BT

GLORIA: Do you want a

"minilip"? At least you won't feel hungry.

Miguel: No, it makes me nervous. Look how you are.

GLORIA: How am I?
S

You want a No-Doze?

You won't feel hungry.

It makes me nervous.

- Look at you.

- What do you mean?

\subsection{Tropes}

Tropes are rhetorical figures of speech in figurative language. They affect the semantics of a text by using words or other signifiers in senses beyond their literal meaning, creating a diversion from the literal to the figurative. The most common tropes are allegory, irony, metaphor, metonymy, oxymoron (paradox), parabola, sarcasm, simile, synaesthesia and synecdoche.

In PLB, Pepi discovers Luci is married to the policeman who raped her, and she asks her for knitting lessons at home. Then she tells Luci about her husband, arguing that she was planning to put her virginity on sale for 60,000 pesetas. Later on in the film, Luci tells her that she knows someone who can rebuild her hymen, so that she can then sell her virginity to the highest bidder. She uses a metaphor with the term zurcido which refers to darning. The English version uses 'mending' which is then further explained in another subtitle with the adverbial clause 'down there' (particularisation). This could have also been functionally solved using the term 'embroidery.'

3. For instance, Marjane Satrapi's graphic novel Broderies (2003), originally in French, tackles the importance of hymen repair among contemporary Islamic women. The term used in the English translation by Anjali throughout the graphic novel, as well as for the title, was 'embroideries'. However, this word has a double meaning to refer to the embellishment or exaggeration in the description of an event, which may be the reason why 'embroidery' was not used in the English version. 
Example no. 11 (PLB)

ST

LuCI: A propósito, Pepi, Luci: By the way, Pepi, de lo que me dijistes [sic] el otro día, yo conozco una mujer que te podría hacer un zurcido.

PEPI: ¿Un qué?

LUCI: ¡Un zurcido!

PEPI: Pero ¿dónde?

LUCI: Ahí.

PEPI: Ah, no. Ya te avisaré. De momento me apetece seguir utilizándolo. about what you told me the other day, I know a woman who could sew you up.

PEPI: Do what?

LUCI: Sew you up!

PEPI: But where?

LUCI: There.

PEPI: Ah, no. I'll let you know. Now I feel like carrying on using it.
S

By the way, Pepi.

What you were saying the other day,

I know a woman who can do your mending.

- Do what?

- Your mending.

Where?

Down there.

I'll let you know.

I'd rather carry on using it for now.

Also in LP, when Sexilia meets her counterparts at her apartment, Angustias offers timid dry cleaner Queti a dildo (un chicle), although she does not understand the pun at first. This metonymy originates in the material of which it is made (rubber), so when Angustias takes the dildo out of her bag, Queti bursts into laughter. Here, the metonymy is literally transferred in the English subtitles, and the double meaning of 'gum' is specified by particularising.

Example no. 12 (LP)

ST

ANGUSTIAS: Mira, yo te voy a dar un chicle, si quieres.

QUETI: Vale, de menta. ANGUSTIAS: ¿De menta? ¿O con sabor a menta? Pero lo tengo eléctrico y de goma, tú verás.
BT

GIRL FRIEND: Look, I'm going to give you a gum, if you want.

QUETI: Ok, mint.

ANGUSTIAS: Mint? Or mint flavour? But I've got electric and rubber.

It's up to you.
$\mathrm{S}$

-I can give you some gum if you want.

-Do you have mint?

Mint flavour?

I have electric and rubber. It's up to you.

In $\mathrm{DH}$, Mother Superior gives Sister Damned some pocket money so that she can go shopping and tells her to be careful with el niño ('the boy'). At this point, the audience is shocked and will be keen to know who this boy is, for 
convent nuns are not allowed to have offspring of their own in the Catholic tradition. Yet the dialogue suggests that Sister Damned may have an illegitimate son (irony). Hence, this wordplay relies on what may be referred to as "surprise reversal and unspoken meaning" (Low 2011: 61) through the use of a metaphor. That very night, the new arrival, drug addict singer Yolanda, looks through the windows and discovers that the so-called 'boy' is actually a Bengal tiger whose roars can be heard from the garden.

Example no. $13(\mathrm{DH})$

ST

MADRE SUPERIORA:

Cuidado con el niño.

Enciérrelo. Que la chica no lo vea, no vaya a

asustarse.

SOR RATA DE CALlEJÓN:

¿Dónde está ahora?
BT

MOTHER SUPERIOR: Be careful with the boy! Lock him up. The girls mustn't see him, or she will be scared. SISTER SEWER RAT: Where is she now?
$S$

Be careful with the boy. Lock him up.

- The girl mustn't see him. - Where is she?

On some occasions, VEH elements may rely on the audience's background knowledge. For instance, in WH, Gloria's mother-in-law has to help her grandson Toni with his homework. The exercise comprises a list of writers that they have to individually classify as either realists or romantics. Granny answers every single question incorrectly and then claims it was very easy (irony). When she answers the last one, Balzac, she nods her head in a way that suggests she is making everything up (paradox). The translator has tried to convey this clue to the audience in the last subtitle ("It sure is."), specifically indicating that previous subtitles were ironic (amplification). These types of VEH elements are likely to be lost in translation should the audience be unable to match the authors with their corresponding literary currents. 
Example no. 14 (WH)

ST

Toni: Dime cuáles de estos autores son románticos y cuáles, realistas. Ibsen.

ABUELA: Romántico.

TONI: Lord Byron.

ABUELA: Ese, realista.

Toni: Goethe.

ABUELA: Realista

también.

Toni: Y Balzac.

ABUELA: Romántico.

¿Ves que fácil?

TONI: Sí.
BT

TONI: Tell me which of these authors are romantic and which are realist. Ibsen.

GRANNY: Romantic.

TONI: Lord Byron.

GRANNY: That one, realist.

Toni: Goethe.

GRANNY: Also realist.

TONI: And Balzac.

GRANNY: Romantic. Do

you see how easy it is?

TONI: Yes.
S

Tell me who are the romantics and who are the realists?

Ibsen.

Romantic.

- Lord Byron.

- Realist.

- Goethe.

- Another realist.

And Balzac.

Romantic.

- See how easy it is?

- It sure is.

\section{Results and applications}

Based on the results in the analysis of the 14 examples above, it can be inferred that the most frequent techniques have been the following, in strictly decreasing order: non-translation (six cases), wordplay replacement (four cases), non-word replacement (three cases) and explanations (one case). It can be argued that none of them have an exceptionally high rate of use, yet it is true that non-translation and wordplay replacement techniques, which are opposite in nature, represent two thirds of the techniques observed in the examples. It has also been found, as illustrated by Perego (2014), that one of the main strategies for VEH content is to mitigate the loss of humour by compensation of humorous instances and adding further layers of meaning in other subtitles.

The films do not seem to present any linguistic tendency regarding VEH transfer in the subtitles. PLB has a total of four examples (two non-translations, one explanation, one wordplay replacement), LP has five (two non-translations, one non-wordplay replacement, two wordplay replacements), DH has one (one non-translation) and $\mathrm{WH}$ has four (one non-translation, two non-wordplay replacements, one wordplay replacement). Hence, techniques seem to have been homogeneously applied throughout the films. Yet interestingly, LP is the film that contains the biggest number of VEH elements that have not been functionally translated. As seen in section 4, PLB, DH and WH are all distributed by Optimum Releasing and can even be bought in a DVD box set, whereas $L P$ is the only film that is distributed by Tartan Video and is not included in 
any DVD box set. Hence, the possibility that the same subtitler carried out the translation of PLB, DH and WH cannot be discarded, although the results of this study do not permit further discussion on the issue of authorship itself.

It must be noted that the use of non-translation techniques does not imply that subtitles may be of a lesser quality. On the contrary, as seen throughout the analysis, some techniques hereby considered as non-translation, such as borrowing and calque, resulted in the functional transfer of wordplay in the subtitles as well (see examples 6, 8 and 13). Substituting or compensating VEH elements that are more acceptable for the new audience (i.e. domestication) may not always be as effective as calquing them in the target language. Instead, it always depends on the context, and especially on the image, which may even be the main trigger of the joke, thus imposing a foreignising approach.

The application of the VEH-specific techniques used throughout this study calls for further investigation in other areas, such as vulnerability, audience perception and relevance theory, to name but a few current red-hot topics in subtitling.

\section{Conclusions}

As seen throughout this paper, humour transfer is of paramount importance when translating audiovisual programmes from a functional perspective, especially when the nature of the source text is strictly related to entertaining the audience (comedy). In the case of the 'early Almodóvar' films, the appearance of VEH elements calls for a functional approach when subtitling them in English because "an adequate transfer [of humour] to the target language and culture is fundamental, for it is in humour where lies the natural principle of functionality" (Fuentes 2004: 77; my translation).

Despite the constraints imposed by subtitling, the translation of VEH content with replacement techniques in different passages renders humorous transfer on screen possible. The polysemiotic nature of audiovisual texts represents a double-edged sword. On the one hand, the presence of image and sound makes subtitling a type of vulnerable translation, and constrains the subtitler's agency. On the other, it represents the perfect justification for the application of creative translation techniques, such as idiomatic compensation, discursive creation, substitution and variation. These techniques, categorised in this study as 'wordplay replacement', respond to a functional approach of VEH transfer that goes beyond their textual nature. It could be stated that carrying out a pre-translation analysis of wordplay, on behalf of the subtitler, in terms of functionality could help preserve the humorous function consistently throughout the subtitling process. 
In the case of the subtitled versions of these 'early Almodóvar' films, VEH elements play an undeniably crucial role throughout. Almodóvar's first four comedies are humorous in nature, and it is thus necessary to maintain consistent translation strategies aimed at preserving the humorous tone. Translation techniques have proven to be the materialisation at the micro-unit level of the latter. These have been analysed as per their effectiveness in transferring VEH elements to the English subtitles by means of functionality. The analysis has also taken into account the particular contextualisation of these four films, which is the Movida social and cultural movement of Spain in the 1980s. This historical period of change in Spain is also representative of the openness and freedom displayed in Almodóvar's scripts. Along with their humorous shifts, Almodóvar's irreverent and visceral dialogues need to be carefully rendered in the subtitles.

To sum up, the analysis has revealed that most VEH elements have been identified, although not all of them have been functionally rendered in English. Some differences have also been observed between the older VHS version and the recent DVD version of $L P$, which does not seem to have been improved very much in terms of VEH content transfer. There does not seem to be an overall translation strategy or method for these 'early' Almodóvar films, although some of the subtitles may indicate a rather foreignising approach. This is something that calls for further research by focusing, within film studies, on Almodóvar's cinematic production and, perhaps, also by taking into account more recent artistic stages of Almodóvar's work.

\section{References}

ATTARDO, Salvatore \& Victor Raskin. (1991) "Script theory revis(it)ed: joke similarity and joke representation model." Humor 4:3-4, pp. 293-347.

AtTARDO, Salvatore. (1994) Linguistic Theories of Humour. Berlin \& New York: Mouton de Gruyter.

ATTARDO, Salvatore. (2002) "Translation and Humour." The Translator 8:2, pp. 173-194.

Ballesteros, Isolina. (2009) "Performing identities in the cinema of Pedro Almodóvar." In: Epps, Brad \& Despina Kakoudaki (eds.) 2009. All about Almodóvar. A passion for cinema. Minneapolis: University of Minnesota Press, pp. 71-100.

BerTHIER, Nancy. (2009) "Pedro Almodóvar : au commencement était la Movida." Cadernos Ceru 20:1, pp. 15-32.

BLAKE, Barry. (2007) Playing with Words. Humour in the English language. London:

Equinox. 
Bolaños García-Escribano, Alejandro. (2014) El cine del "primer Almodóvar» (1980-1984) en la España de la movida. Sevilla: Universidad Pablo de Olavide. Unpublished Dissertation.

BuZELIN, Hélène. (2013) "Sociology and translation studies." In: Millán, Carmen \& Francesca Bartrina (eds.) 2013. The Routledge handbook of translation studies. Abingdon: Routledge, pp. 186-200.

Chaume Varela, Frederic. (2004) "Film Studies and Translation Studies: Two Disciplines at Stake in Audiovisual Translation." Meta : journal des traducteurs / Meta: Translators' Journal 49:1, pp. 12-24.

CHIARO, Delia. (1992) The Language of Jokes. Analysing verbal play. London: Routledge.

ChiAro, Delia. (2006) "Verbally Expressed Humour on Screen: Reflections on Translation and Reception." The Journal of Specialised Translation 6, pp. 198-208.

Chiaro, Delia. (2010) "Translating Humour in the Media." In: Chiaro, Delia (ed.) 2010. Translation, Humour and the Media. London: Continuum, pp. 1-16.

CORnu, Jean-François. (2014) Le doublage et le sous-titrage. Histoire et esthétique. Rennes: Presses Universitaires de Rennes.

Crystal, David. (1998) Language Play. Harmondsworth: Penguin.

Delabastita, Dirk. (1993) There's a double tongue: an investigation into the translation of Shakespeare's wordplay, with special reference to Hamlet. Amsterdam: Rodopi.

Delabastita, Dirk. (1996) "Introduction." In: Delabastita, Dirk (ed.) 1996 Wordplay and Translation: Essays on Punning and Translation, Special issue of The Translator 2:2, pp. 1-22.

De RosA, Gian Luigi; Francesca Bianchi; Antonella De Laurentiis \& Elisa Perego (eds.) (2014) Translating Humour in Audiovisual Texts. Oxford: Peter Lang.

DíAz CinTAS, Jorge. (2001) "Sex, (sub)titles and videotapes." In: Lorenzo, Lourdes

\& Ana María Pereira (eds.) 2001. Traducción subordinada II: el subtitulado (inglés-español/galego). Vigo: University of Vigo, pp. 47-67.

DíAz CinTAS, Jorge. (2003) Teoría y práctica de la subtitulación. Inglés-Español. Barcelona: Ariel Cine.

DíAz CinTAS, Jorge. (2005) "Teoría y traducción audiovisual." In: Zabalbeascoa, Patrick; Laura Santamaria \& Frederic Chaume (eds.) 2005. La traducción audiovisual. Investigación, enseñanza y profesión. Granada: Comares, pp. 9-21.

DíAz CinTAS, Jorge \& Aline Remael. (2007) Audiovisual Translation: Subtitling. Manchester: St Jerome.

FOUCE, Héctor. (2000) "La cultura juvenil como fenómeno dialógico: reflexiones en torno a la movida madrileña." Cuadernos de Información y Comunicación 5, pp. 267-275. 
FUENTES LUQUE, Adrián. (2000) La recepción del humor audiovisual traducido: estudio comparativo de fragmentos de las versiones doblada y subtitulada al español de la película Duck Soup, de los Hermanos Marx. Granada: Universidad de Granada. Unpublished doctoral dissertation.

Fuentes LuQue, Adrián. (2004) "Reír o no reír, esa es la cuestión: la traducción del humor verbal audiovisual. Estudio descriptivo de un fragmento de Duck Soup, de los Hermanos Marx." Puentes 3, pp. 77-85.

Fuentes LuQue, Adrián. (2010) "On the (Mis/Over/Under)Translation of the Marx Brothers' Humour." In: Chiaro, Delia (ed.) 2010. Translation, Humour and the Media. London: Continuum, pp. 175-192.

GARZELli, Beatrice. (2014) "Lo humor di Almodóvar tradotto in italiano. Casi emblematici di doppiaggio e sottotitolaggio in ¡Átame!, La flor de mi secreto e Todo sobre mi madre." In: de Rosa, Gian Luigi; Francesca Bianchi; Antonella De Laurentiis \& Elisa Perego (eds.) 2014. Translating Humour in Audiovisual Texts. Bern: Peter Lang.

GotTlieb, Henrik. (1997a) Subtitles, Translation \& Idioms. Copenhagen: University of Copenhagen. Unpublished doctoral dissertation.

Gottlieb, Henrik. (1997b) "You Got the Picture? On the Polysemiotics of Subtitling Wordplay.” In: Delabastita, Dirk (ed.) 1997. Traductio. Essays on Punning and Translation. Manchester: St Jerome.

GUBERN, Roman. (2014) "Movida y transgresión en el primer Almodóvar." In: Poyato Sánchez, Pedro (ed.) 2014. El cine de Almodóvar. Una poética de lo "Trans." Coria: International University of Andalusia, pp. 15-27.

HousE, Juliane. (2016) Translation as Communication across Languages and Cultures. Abingdon: Routledge.

Hurtado AlBiR, Amparo \& Lucía Molina Martínez. (2002) "Translation Techniques Revisited: A Dynamic and Functionalist Approach.” Meta : journal des traducteurs / Meta: Translators' Journal 47:4, pp. 498-512.

IVARSSON, Jan \& Mary Carroll. (1998) Subtitling. Simrishamn: TransEdit HB.

LiPKA, Leonhard. (2009) "Non-serious Text Types, Comic Discourse, Humour, Puns, Language Play, Limericks, Punning and Joking." Journal of Theoretical Linguistics 6:1, pp. 84-91.

LOMEÑa GALIANO, María. (2009) "Variación lingüística y traducción para el doblaje: Mujeres al borde de un ataque de nervios." Entreculturas 1, pp. 275-283.

Low, Peter Alan. (2011) “Translating jokes and puns." Perspectives 19:1, pp. 59-70. MARTínEZ SiERRA, Juan José. (2004) Estudio descriptivo y discursivo de la traducción del humor en textos audiovisuales. El caso de Los Simpson. Castelló de la Plana: Universitat Jaume I. Unpublished doctoral dissertation.

MARTínez Sierra, Juan José. (2008) Humor y traducción. Los Simpson cruzan la frontera. Castelló de la Plana: Publicacions de la Universitat Jaume I. 
Martínez Vasseur, Pilar. (2004) "La España de los 80 en el cine de Pedro Almodóvar." In: Ruzafa Ortega, Rafael (ed.) 2004. La historia a través del cine: Transición y consolidación democrática en España. Bilbao: Servicio de Publicaciones de la Universidad del País Vasco, pp. 167-202.

MAYORAL, Roberto; Dorothy Kelly \& Natividad Gallardo. (1988) "Concept of constrained translation. Non-linguistic perspectives of translation." Meta : journal des traducteurs / Meta: Translators' Journal 33:3, pp. 356-367.

MEYER, John C. (2000) "Humor as a Double-Edged Sword: Four Functions of Humor in Communication." Communication Theory 10:3, pp. 310-331.

NASH, Walter. (1985) The Language of Humour. Style and technique in comic discourse. London: Longman.

NORD, Christiane. (1997) Translating as a Purposeful Activity: Functionalist Approaches Explained. Manchester: St Jerome.

Perego, Elisa. (2014) "Humour and audiovisual translation: an overview." In: De Rosa, Gian Luigi; Francesca Bianchi; Antonella De Laurentiis \& Elisa Perego (eds.) 2014. Translating Humour in Audiovisual Texts. Oxford: Peter Lang, pp. 9-14.

PÉREz GOnZÁlez, Luis. (2014) Audiovisual Translation Theories, Methods and Issues. London: Routledge.

REDFERn, Walter. (1986) Puns. Oxford: Basil Blackwell.

Romero, Lupe. (2011) "When Orality Is Less Pre-fabricated: An Analytical Model for the Study of Colloquial Conversation in Audiovisual Translation." In: Incalcaterra McLoughlin, Laura; Marie Biscio \& Máire Áine Ní Mhainnín (eds.) 2011. Audiovisual Translation Subtitles and Subtitling. Theory and practice. Oxford: Peter Lang, pp. 55-86.

Ross, Alison. (1998) The Language of Humour. London: Routledge.

Roussou, María. (2005) "La subtitulación de tres filmes de Almodóvar al griego: estudio descriptivo." Puentes 6, pp. 61-68.

Rox Barasoain, María. (2008) The Films of Pedro Almodóvar: Translation and Reception in the United States. León: Universidad de León. Unpublished doctoral dissertation.

SCHRÖTER, Thorsten. (2010) "Language-play, Translation and Quality - with Examples from Dubbing and Subtitling." In: Chiaro, Delia (ed.) 2010. Translation, Humour and the Media. London: Continuum, pp. 138-152.

SCHWARZ, Jeannine. (2010) Linguistic Aspects of Verbal Humour in Stand-up Comedy. Saarbrücken: Universität des Saarlandes. Unpublished doctoral dissertation.

SEN, Anindya. (2012) "Humour Analysis and Qualitative Research." Social Research Update 63, pp. 1-4.

VANDAELE, Jeroen. (2010) "Humour in translation." In: Gambier, Yves \& Luc van Doorslaer (eds.) 2010. Handbook of Translation Studies, vol. I. Amsterdam: John Benjamins, pp. 147-152. 
VANDAELE, Jeroen. (2011) "Wordplay in Translation." In: Gambier, Yves \& Luc van Doorslaer (eds.) 2011. Handbook of Translation Studies, vol. II. Amsterdam: John Benjamins, pp. 180-183.

VARGA, Cristina. (2011) “Traduire pour rire. Arthur et les chevaliers de la télé." In: Şerban, Adriana \& Jean-Marc Lavaur (eds.) 2011. Traduction et medias audiovisuels. Villeneuve d'Ascq: Presses Universitaires du Septentrion, pp. 139-155.

VEATCH, Thomas C. (1998) "A theory of humor." Humor 11:2, pp. 161-215.

VEIGA, Maria José. (2009) "The Translation of Audiovisual Humour in Just a Few Words.” In: Díaz Cintas, Jorge (ed.) 2009. New Trends in Audiovisual Translation. Bristol: Multilingual Matters, pp. 158-194.

Zabalbeascoa Terrán, Patrick. (1996) "Translating Jokes for Dubbed Television Situation Comedies." The Translator 2:2, pp. 253-257.

Zabalbeascoa Terrán, Patrick. (2001) "La traducción del humor en los textos audiovisuales." In: Duro Moreno, Miguel (ed.) 2001. La traducción para el doblaje y la subtitulación. Madrid: Cátedra, pp. 267-298.

\section{BIONOTE / NOTA BIOGRÁFICA}

Alejandro Bolaños García-Escribano is a $\mathrm{PhD}$ candidate and Teaching Fellow at University College London's Centre for Translation Studies thanks to a La Caixa Social Foundation studentship. He holds a joint bachelor's degree on Translation and Humanities Studies from Pablo de Olavide University (Seville), a master's degree on Translation applied to the Publishing Industry from the University of Malaga, and a master of science on Audiovisual Translation from University College London's Centre for Translation Studies. He is currently carrying out research on the pedagogical potential of subtitling and cloud-based systems in collaboration with subtitling software developers. He also works as a freelance translator, subtitler and teacher in London.

ALEJANDRO BOLAÑOS GARCÍA-ESCRIBANO es estudiante de doctorado y profesor asistente del Centre for Translation Studies en University College London gracias a una beca de la Obra Social La Caixa. Se graduó en Humanidades y Traducción e Interpretación por la Universidad Pablo de Olavide de Sevilla, y ha cursado el Máster Universitario en Traducción para el Mundo Editorial de la Universidad de Málaga y el máster de Traducción Audiovisual del Centre for Translation Studies en University College London. En la actualidad investiga el potencial pedagógico de las herramientas de subtitulación y plataformas en la nube en colaboración con desarrolladores de software de subtitulación. Asimismo, trabaja como traductor, subtitulador y profesor autónomo en Londres. 
